\title{
PENINGKATAN EKSISTENSI ORGANISASI SISWA INTRA SEKOLAH (OSIS) SE KOTA PEKANBARU MELALUI KONSEP MANAJEMEN DAN KEPEMIMPINAN
}

\author{
M.Zainuddin', Amir Syamsuadi ${ }^{1}$, Mhd.Rafi Yahya ${ }^{1}$ \\ 1) Program Studi Ilmu Pemerintahan, Fakultas Ilmu Sosial Politik, Universitas Abdurrab \\ *Email: zainuddin@univrab.ac.id
}

\begin{abstract}
ABSTRAK
Organisasi Siswa Intra Sekolah (OSIS) merupakan salah satu sarana pengembangan minat dan bakat siswa di internal sekolah. Eksistensi OSIS ini dapat bermanfaat untuk sekolah dan masyarakat. OSIS juga merupakan komponen utama dari sekolah yang menjadi pioneer untuk perkembangan yang ada di sekolah. Permasalahannya adalah banyak OSIS yang tidak menunjukkan eksistensi dirinya sebagai motor penggerak perkembangan sekolah dan siswa. Kevakuman OSIS ini lebih disebabkan pada rendahnya pemahaman tentang konsep manajemen dan kepemimpinan, sehingga anggota yang potensial tidak dapat terkelola dengan baik. Kegiatan pengabdian ini dilaksanakan dengan cara memberikan pelatihan dan pendampingan program selama 1 bulan. Akibat dari kegiatan ini adalah meningkatnya eksistensi OSIS di sekolah dan bermanfaat bagi siswa dan masyarakat, terbentuknya asosiasi OSIS se Kota Pekanbaru sebagai wadah untuk berdiskusi dalam hal meningkatkan eksistensi OSIS dan berkontribusi bagi pembangunan manusia di Pekanbaru.
\end{abstract}

Kata Kunci: pelatihan, OSIS, eksistensi, manajemen, kepemimpinan

\begin{abstract}
Internal School Student Organization (OSIS) is one means of developing interests and talents of students in the school's internal. The existence of this organization can be beneficial for the school and community. OSIS is also a major component of the school who became a pioneer for the development of schools. The problem is that many OSIS that does not show the existence itself as a motor of development of the school and students. OSIS vacuum is more due to the lack of understanding of the concepts of management and leadership, so that potential members can not be managed properly. This service activities carried out by providing training and mentoring program for 1 month. As a result of this activity is the growing existence of the OSIS at school and beneficial for students and the community, produce of the association OSIS as the city of Pekanbaru as a forum for discussion in terms of enhancing the existence of the OSIS and contribute to human development in Pekanbaru.
\end{abstract}

Keywords: training, OSIS, existence, management, leadership 


\section{PENDAHULUAN}

Organisasi Siswa Intra Sekolah (OSIS) merupakan kelompok siswa yang terorganisir untuk menciptakan suasana sekolah yang tidak kaku dan monoton karena belajar di dalam kelas saja. Keseimbangan otak kiri dan kanan siswa perlu diasah di sekolah dengan berbagai sarana yang ada. OSIS, keberadaannya mulai pada masa orde baru sebagai upaya supaya siswa tidak memiliki atau ikut organisasi terlarang dan menyimpang yang ada di luar sekolah. Harapannya, OSIS menjadi alat utama siswa dalam pengembangan diri dalam pola organisasi.

Seiring dengan perkembangan zaman, OSIS di setiap sekolah mengalami penurunan aktifitas dan kreatifitas. Banyak faktor yang bisa dijadikan alasan, mulai dari sifat hedonisme kaum remaja, sehingga tidak mau berbuat untuk orang lain hingga faktor rendahnya tingkat pemahaman pada pengelolaan organisasi. Kemajuan sebuah organisasi harus ditopang dengan pemahaman konsep manajemen dan kepemimpinan oleh para pemangku kebijakan organsisasi tersebut. Kealpaan pada pemahaman tersebut dapat mengakibatkan pada rendahnya produktifitas organisasi dalam berkontribusi.

Manajemen merupakan konsep untuk mengelola sesuatu. Sementara kepemimpinan atau leadership adalah kemampuan seseorang untuk mempengaruhi orang-orang lain agar bekerjasama sesuai dengan rencana demi tercapainya tujuan yang telah ditetapkan sebelumnya. Dengan demikian kepemimpinan memegang peranan yang sangat penting dalam manajemen di organisasi atau lembaga, bahkan dapat dinyatakan, kepemimpinan adalah inti dari manajemen. Untuk mewujudkan hal tersebut maka perlu menumbuhkan jiwa kepemimpinan semenjak dini pada kalangan siswa.

Siswa merupakan bagian dari generasi muda Indonesia. Siswa memperoleh peluang yang sangat besar untuk mengembangkan dirinya sebagai manusia yang berkualitas dan berintegritas. Siswa sebagai masyarakat terpelajar merupakan kaum intelektual muda yang diharapkan punya kreatifitas yang tinggi baik di bidang akademik maupun bidang non akademik. Dalam proses pembangunan, siswa merupakan kekuatan pembangunan yang sekaligus harus dibangun sehingga menjadi manusia yang mampu mewujudkan masa depan yang baik.

Di sisi lain, siswa juga menjadi ujung tombak perubahan tentunya ada pada generasi siswa yang terpelajar seperti pelajar di tingkat menengah atas (SMA dan MA). Namun, paradoks terjadi, pelajar yang seharusnya menjadi ujung tombak perubahan ke arah positif, justru jauh menyimpang dari harapan yang diinginkan. Jika kita tanya kepada orang tua, label yang tepat bagi pelajar hari ini adalah mereka yang tidak siap untuk dititipkan amanah untuk menjadi pemimpin. Hal ini tentunya punya alasan, dimana pelajar sekarang lebih dekat dengan narkoba, seks bebas, pergaulan yang tidak bernilai positif, dan segala prilaku negatif melekat pada mereka. Tidak ada lagi harapan untuk menitipkan amanah besar kepada mereka. Kalaupun ada, itu hanya sebagian kecil. Banyak pelajar yang berprestasi, tapi terkadang tidak dibekali dengan iman kepada tuhannya. Pelajar yang tidak beriman ini, akan membawa petaka bagi generasi kepemimpinan bangsa ini ke depannya.

Siswa yang nantinya sebagai agent of changes dan agent of social control merupakan pionir dan tonggak dari sebuah pembangunan dan perubahan sosial. Siswa terpelajar yang memiliki pemahaman kepemimpinan diharapkan mampu menjadi penerus bangsa yang merubah wajah dunia nantinya. Siswa juga diidentikan dengan kaum terpelajar yang mampu berpikir kritis terhadap segala permasalahan-permasalahan yang tengah ada. Siswa juga berkaitan erat dengan organisasi dan keterampilan. Keterampilan merupakan suatu hal yang hendaknya dikuasai oleh siswa semenjak dini agar dapat melaksanakan fungsinya dalam kehidupan dan berorganisasi dengan baik 
Untuk itu diperlukan suatu kegiatan yang dapat melatih dan membimbing siswa menjadi pemimpin-pemimpin yang cerdas, berkarakter, memiliki visi kedepan dan berintegritas. Salah satunya melalui kegiatan pelatihan untuk eksistensi OSIS yang merupakan agenda pengabdian dosen Ilmu Pemerintahan Universitas Abdurrab.

Kegiatan ini ditujukan kepada pengurus OSIS SLTA se Kota Pekanbaru, karena Organisasi Siswa Intra Sekolah ini menjadi momen untuk merefleksikan komitmen perubahan yang dilakukan oleh generasi terpelajar di tengah-tengah masyarakat ilmiah, sekaligus menyumbangkan perubahan menuju Indonesia baru yang hebat dan bermartabat, maka melalui generasi muda yang memiliki pemahaman akan suatu kepemimpinan dalam manejemen organisasilah semua akan bisa terwujud.

Melatih kepemimpinan semenjak dini di Riau menjadi manifestasi kepemimpinan nasional ke depannya. Di tingkat wacana, training ini juga bertujuan untuk mengangkat perspektif moral dan akhlak seorang pemimpin yang religius untuk membangun kepemimpinan baru yang visioner, berintegritas, dinamis, dan beradab. Selanjutnya di tingkat gerakan (praktis), diagendakan usaha mengusung ajakan moral akan keprihatinan terhadap problematika umat dan bangsa.

Adapun permasalahan pengurus OSIS di Kota Pekanbaru adalah: Pertama, kurangnya pemahaman pengurus OSIS untuk mengelola organisasi intra sekolah. Kedua, tidak ada proses kaderisasi kepemimpinan di tingkat sekolah yang dilakukan secara simultan atau berkelanjutan. Ketiga, ada penurunan tingkat keaktifan pengurus yang dapat dilihat dari rendahnya persentase kegiatan yang dilakukan setiap tahunnya. Berdasarkan permasalahan tersebut, maka fokus masalah yang diselesaikan dalam kegiatan pengabdian ini adalah menumbuhkan kemampuan manajemen dan karakter kepemimpinan dari siswa.

Kegiatan pengabdian kepada masyarakat dalam bentuk pelatihan dan pembinaan manajemen dan kepemimpinan ini diselenggarakan dengan tujuan: Pertama, memberikan pemahaman manajemen dan kepemimpinan organisasi bagi siswa. Kedua, membentuk karakter leadership pada diri sejak dini. Ketiga, sebagai langkah awal proses pembinaan siswa yang intensif, berkelanjutan dan terprogram. Keempat, membentuk pengurus OSIS yang memiliki kemampuan manajerial yang mapan dan kreatif. Kelima, mengantisipasi pelajar sebagai objek politik belaka. Keenam, mengidentifikasi perilaku politik pelajar dan kegiatan politik yang diperbolehkan bagi pelajar.

Berdasarkan tujuan tersebut, maka kegiatan ini memberikan manfaat pada: Pertama, penciptaan pengurus OSIS yang mandiri, kreatif dan berdaya guna. Kedua, dapat membantu stakeholder sekolah dalam mengelola berbagai kegiatan. Ketiga, meningkatkan eksistensi sekolah melalui kegiatan siswanya. Keempat, terciptanya komunitas yang produktif dan bermanfaat, terutama komunitas pengurus OSIS di tingkat SLTA se Kota Pekanbaru.

\section{A. BAHAN DAN METODE}

Kegiatan pelatihan dan pembinaan manajemen dan kepemimpinan OSIS SLTA dilakukan selama 4 minggu, dengan durasi waktu 2 jam/hari, dilaksanakan selama 1 kali dalam seminggu. Namun, untuk kegiatan awal dilakukan selama 4 jam. Total waktu pelaksanaannya adalah 10 jam. Kegiatan ini dilakukan pada pagi hari minggu. Selama 3 minggu digunakan untuk melakukan pendampingan kegiatan pengurus OSIS oleh tim pengabdian.

Pemandu latihan ini adalah ketua tim pengabdian yang dibantu oleh 2 orang anggota tim dari dosen Ilmu Pemerintahan dan 9 orang mahasiswa Ilmu Pemerintahan. Dosen pada tim pengabdian ini bertugas untuk menyampaikan materi dan pendampingan, sementara mahasiswa berperan untuk membantu administrasi dan memberikan ice breaking. 
Pelatihan ini dilakukan secara terintegrasi atau digabungkan di suatu tempat, sebab, metode pelatihan yang digunakan adalah diskusi dan menggali kemampuan masing-masing peserta, sehingga memungkinkan untuk saling bertukar fikiran antar sesama peserta. Hal ini sifatnya positif dan tentu akan mengundang perhatian pengurus OSIS yang belum berpartispasi. Harapannya, akan ada siswa yang lain untuk bergabung ikut pada kegiatan pelatihan tersebut. Materi pelatihannya meliputi: Ekspektasi Peserta, Pengantar Leadership, Manajemen dan Pengantar Organisasi, Problem Solving, dan Ice Breaking.

Selain adanya kepuasan pihak sekolah, maka alat ukur lainnya dapat berupa terbentuknya asosiasi OSIS di Kota Pekanbaru. Asosiasi ini akan berperan sebagai ajang tukar fikiran bagi sesama pengurus OSIS atau dapat bekerja sama dalam melaksanakan berbagai kegiatan.

\section{B. HASIL DAN PEMBAHASAN}

\section{Argumentasi Ilmiah}

\section{a. Konsep Manajemen}

Nursyaidah mengulas beberapa pendapat tentang fungsi manajemen, diantaranya pendapat Steer (1985) bahwa peranan manajemen sangat ditentukan oleh fungsi-fungsi manajemen [1]. Fungsi-fungsi inilah yang menjadi inti dari manajemen itu sendiri. Fungsifungsi tersebut merupakan proses yang harus dilaksanakan oleh semua pihak yang terlibat dalam organisasi. Menurut Nursyaidah, Fungsi-fungsi ini pula yang akan menentukan berhasil atau tidaknya kinerja manajemen [1].

Harold Koonzt dan C. O. Donnel berpendapat lain, bahwa fungsi manajemen terdiri dari: planning, organizing, staffing, directing dan controlling. Namun pada umumnya yang banyak dikenal orang tentang fungsi manajemen adalah istilah POAC: planning (perencanaan), organizing (pengorganisasian), actuating (pelaksanaan), dan cotrolling (pengendalian). Harold Koonzt dan O. Donnel membagi leading (pengarahan), menjadi dua bagian, yakni staffing (kepegawaian) dan directing (pengarahan). Keempat unsur manajemen tersebut merupakan proses manajemen yang memiliki keterkaitan yang erat satu sama lain dalam rangka mencapai tujuan [1].

Sondang P. Siagian menyatakan bahwa fungsi dari manajemen itu adalah berupa perencanaan, pengorganisasian, pemotivasian, pengawasan, dan penilaian [2]. Dapatlah dikatakan bahwa fungsi dasar manajemen yang paling penting adalah merencanakan, mengorganisasi, memimpin, dan mengendalikan. Di lain pihak, menurut Fayol, fungsi manajemen itu sama seperti fungsi administrasi, yakni merencanakan, mengorganisasikan, mengarahkan, mengkoordinasikan, mengontrol atau mengendalikan [1].

\section{b. Konsep Kepemimpinan}

Agama telah mengajarkan kepada kita bahwa dalam diri setiap manusia terdapat tugas sebagai pemimpin, dan setiap pemimpin akan dimintai pertanggungjawabannya. Oleh sebab itu, siapapun manusianya pasti menyandang gelar pemimpin, baik secara konkrit maupun abstrak atau baik secara formal maupun informal.

Slamet menyebutkan bahwa kepemimpinan merupakan suatu kemampuan, proses, atau fungsi pada umumnya untuk mempengaruhi orang-orang agar berbuat sesuatu dalam rangka mencapai tujuan tertentu. Selanjutnya dikemukakan oleh Slamet bahwa kepemimpinan penting dalam kehidupan bersama dan kepemimpinan itu hanya melekat pada orang dan kepemimpinan itu harus mengena kepada orang yang dipimpinnya. Hal ini berarti harus diakui secara timbal balik, misalnya sasaran yang dipimpin harus mengakui bahwa orang tersebut adalah pemimpinnya [3]. 
Kepemimpinan adalah suatu upaya untuk mempengaruhi pengikut bukan dengan paksaan untuk memotivasi orang mencapai tujuan tertentu. Hubungan pemimpin dengan anggota berkaitan dengan derajat kualitas emosi dari hubungan tersebut, yang mencakup tingkat keakraban dan penerimaan anggota terhadap pemimpinnya. Semakin yakin dan percaya anggota kepada pemimpinnya, semakin efektif kelompok dalam mencapai tujuannya [3].

Faktor-faktor penting yang terdapat dalam pengertian kepemimpinan: (1) pendayagunaan pengaruh, (2) hubungan antar manusia, (3) proses komunikasi dan (4) pencapaian suatu tujuan. Kepemimpinan tergantung pada kuatnya pengaruh yang diberi serta intensitas hubungan antara pemimpin dengan pengikut [4].

Seorang pemimpin harus dapat melakukan sesuatu bagi anggotanya sesuai dengan jenis kelompok yang dipimpinnya. Ada beberapa hal yang perlu dilakukan oleh pemimpin untuk dapat mendinamiskan kelompok, yaitu: (1) mengidentifikasi dan menganalisis kelompok beserta tujuannya, (2) membangun struktur kelompok, (3) inisiatif, (4) usaha pencapaian tujuan, (5) mempermudah komunikasi dalam kelompok, (6) mempersatukan anggota kelompok, dan (6) mengimplementasikan filosofi (Slamet, 2002). Robinson dalam (Ginting 1999) mengemukakan bahwa peranan yang perlu ditampilkan pemimpin adalah: (1) mencetuskan ide atau sebagai seorang kepala, (2) memberi informasi, (3) sebagai seorang perencana, (4) memberi sugesti, (5) mengaktifkan anggota, (6) mengawasi kegiatan, (7) memberi semangat untuk mencapai tujuan, (8) sebagai katalisator, (9) mewakili kelompok, (10) memberi tanggung jawab, (11) menciptakan rasa aman dan (12) sebagai ahli dalam bidang yang dipimpinnya. Sebagai pemimpin kelompok, seseorang harus berperan mendorong anggota beraktivitas sambil memberi sugesti dan semangat agar tujuan dapat tercapai. Semua masukan, baik berupa ide atau gagasan, tekanan-tekanan, maupun berupa materi, semuanya harus diproses di bawah koordinasi pemimpin [4].

Nursyaidah menyebutkan bahwa pemimpin memiliki peranan yang dominan dalam sebuah organisasi. Peranan yang dominan tersebut dapat mempengaruhi moral, kepuasan kerja, keamanan, kualitas kehidupan kerja dan terutama tingkat prestasi suatu organisasi. Sebagaimana dikatakan Hani Handoko bahwa pemimpin juga memainkan peranan kritis dalam membantu kelompok organisasi, atau masyarakat untuk mencapai tujuan mereka [1].

\section{c. Kerangka Pemikiran Kegiatan}

Gambar 1. Kerangka Pemikiran Kegiatan

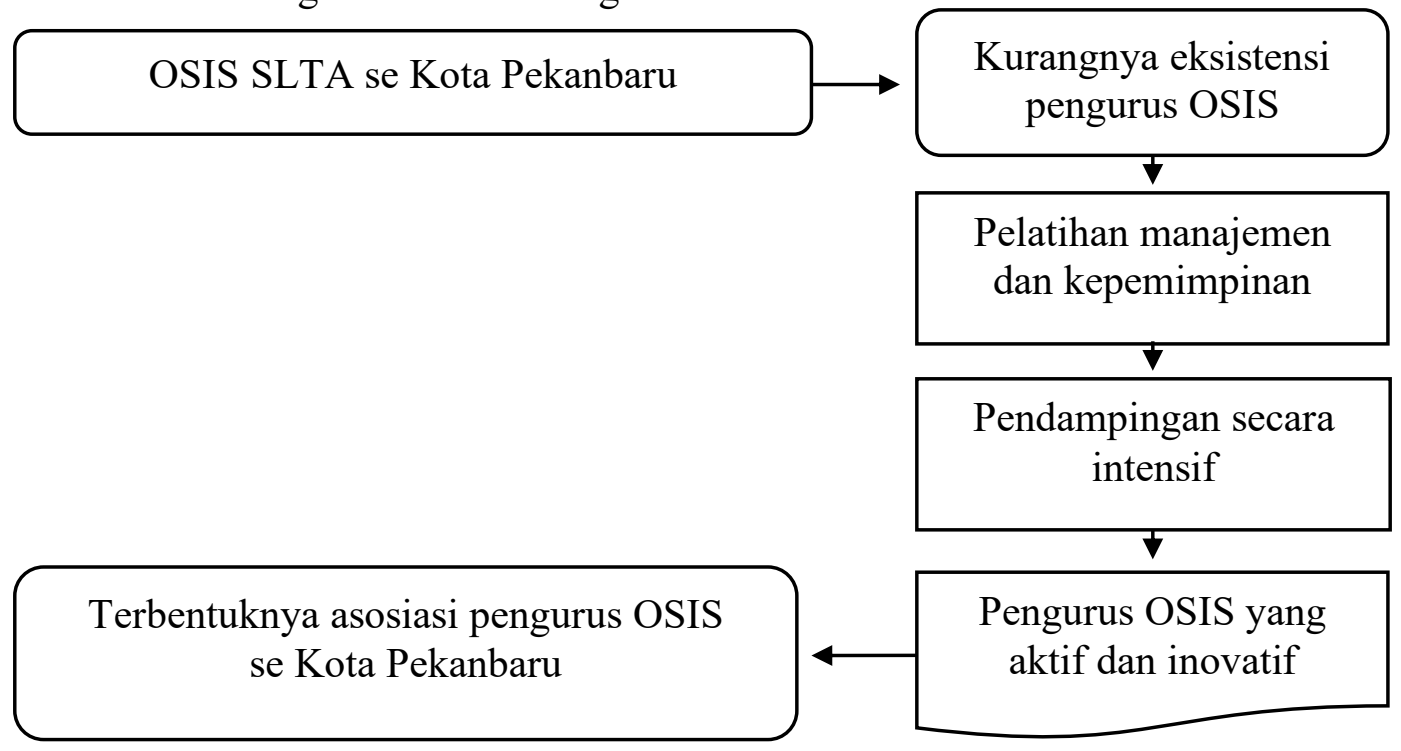




\section{d. Hasil Pelatihan dan Pembinaan}

Pelatihan telah dilaksanakan sebanyak 1 kali dan pembinaan sebanyak 3 kali. Pelatihan yang diikuti oleh 10 sekolah tersebut terlaksana dengan menggunakan metode diskusi. Pengurus OSIS antusias untuk berdiskusi karena topik-topik diskusi yang disajikan oleh tim pengabdi sesuai dengan permasalahan yang mereka hadapi.

Setelah dilaksanakan pelatihan, maka dilakukan pembinaan secara intensif. Pembinaan yang dilakukan dengan metode hadir ke sekolahnya langsung. Permasalahan yang didiskusikn pada saat pembinaan adalah masalah yang sedang dihadapi oleh setiap pengurus OSIS dan secara bersama-sama mencarikan solusi. Pembinaan ini juga dilakukan dengan melibatkan beberapa OSIS untuk berkumpul dengan metode bahwa sekolah yang lebih maju memberikan masukan kepada sekolah lainnya. Dalam hal ini adalah MAN 1 Pekanbaru sebagai OSIS yang dianggap telah mapan. Kemapanan OSIS MAN 1 Pekanbaru ini disebabkan oleh proses kaderisasi yang relatif berfungsi setiap tahunnya dengan dilaksanakannya pelatihan oleh sekolah setiap tahunnya.

Pelatihan OSIS ini menghasilkan generasi yang siap memimpin OSIS sebagai regenerasi OSIS di setiap sekolah dan siap menjadi pemimpin di masyarakat serta pada jenjang organisasi di universitas. Proses menciptakan karakter kepemipinan yang memahami manajemen telah ditanamkan kepada seluruh peserta pelatihan.

Tahap menciptakan karakter kepemimpinan yang memahami manajemen dengan baik tidak cukup hanya dengan melaksanakan satu kali pelatihan kepemimpinan saja, melainkan harus dilakasanakan pelatihan yang serupa dan linear secara simultan. Selain itu, pembinaan yang intensif juga dilakukan. Proses kaderisasi simultan ini akan terus terlaksana secara beregenerasi untuk tiap tahunnya, sehingga akan tercipta budaya kaderisasi sebelum para pengurus OSIS melakukan rekrutmen pengurus OSIS di setiap sekolah.

Proses menciptakan kepemimpinan yang berkarakter dan memiliki kepahaman manajemen sangat diperlukan dan saling keterkaitan. Hubungan antara kepemimpinan dengan manajemen serta sangat erat. Hubungan yang erat ini melibatkan usaha kerja sama antara dua orang atau lebih, untuk mencapai tujuan yang telah ditetapkan. Manajemen peran serta (participative management) adalah suatu pendekatan manajemen yang melibatkan bawahan dalam proses pengambilan keputusan. Keterlibatan secara aktif dari bawahan dengan menggunakan segala keahlian dan kreativitas mereka dalam memecahkan persoalanpersoalan manajemen yang penting. Pelaksanaan manajemen peran serta yang berdasarkan shared authority dari atasan dengan bawahannya tidak berarti atasan melimpahkan semua wewenangnya atau mengurangi wewenangnya dalam pengambilan keputusan melainkan menyertakan bawahan membuat keputusan dalam memecahkan persoalan manajemen yang penting [5].

Pelatihan ini dilakukan pada tempat yang berbeda-beda. Harapannya adalah untuk mendapatkan suasana yang bisa dijadikan objek diskusi dan membuat lebih menyenangkan. Adapun tempat yang menjadi objek pelatihan dan pembinaan pada kegiatan pengabdian ini adalah:

1. Aula Kantor Walikota Pekanbaru. Lokasi ini dipilih supaya dapat memberikan motivasi kepemimpinan untuk masa mendatang. Usaha lobi-lobi pemerintah sangat diperlukan untuk mencapai tujuan organisasi seperti OSIS. Perlu juga menanamkan sikap kritis kepada pemerintah serta dapat menjalin kerja sama dengan pemerintah dalam hal melakukan kegiatan di kalangan pelajar. Kegiatan di lokasi milik pemerintah ini menjadi bukti bahwa inilah manfaatnya menjalin kerja sama dengan pemerintah. Para peserta dapat belajar secara langsung kepada panitia dan berdiskusi langsung dengan pemerintah tentang proses kerja sama. 
Gambar 2. Pelatihan di Aula Kantor Walikota Pekanbaru, dibimbing oleh mahasiswa Ilmu Pemerintahan Universitas Abdurrab

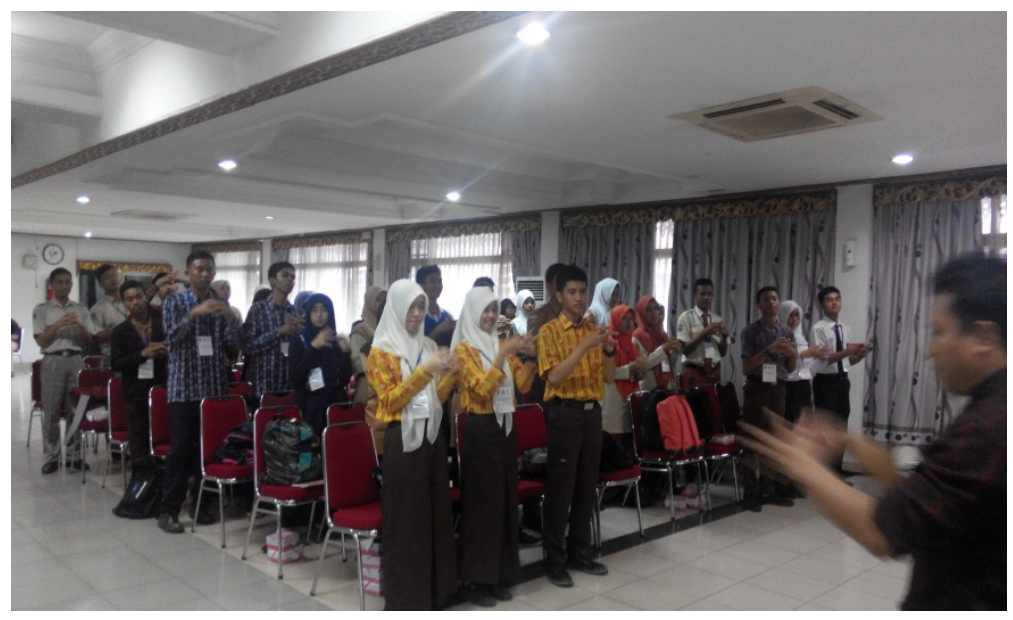

2. Taman Hutan Kota Pekanbaru. Pilihan lokasi ini bertujuan untuk mendekatkan peserta pada alam. Bermain dengan alam sambil mengambil manfaat tentang manajemen dan kepemimpinan di alam terbuka seperti hutan merupakan pilihan yang tepat. Banyak kondisi alam yang bisa dipakai untuk dijadikan contoh tentang manajemen dan kepemimpinan. Hubungan antar makhluk hidup merupakan contoh proses manajemen dan karakter kepemimpinan yang mudah dipahami oleh seluruh peserta. Tema materi yang didiskusikan adalah problem solving, dan manajemen. Di lokasi ini lebih banyak menggunakan ice breaking dan tadabbur alam.

Gambar 3. Proses Pelatihan di Taman Hutan Kota Pekanbaru.
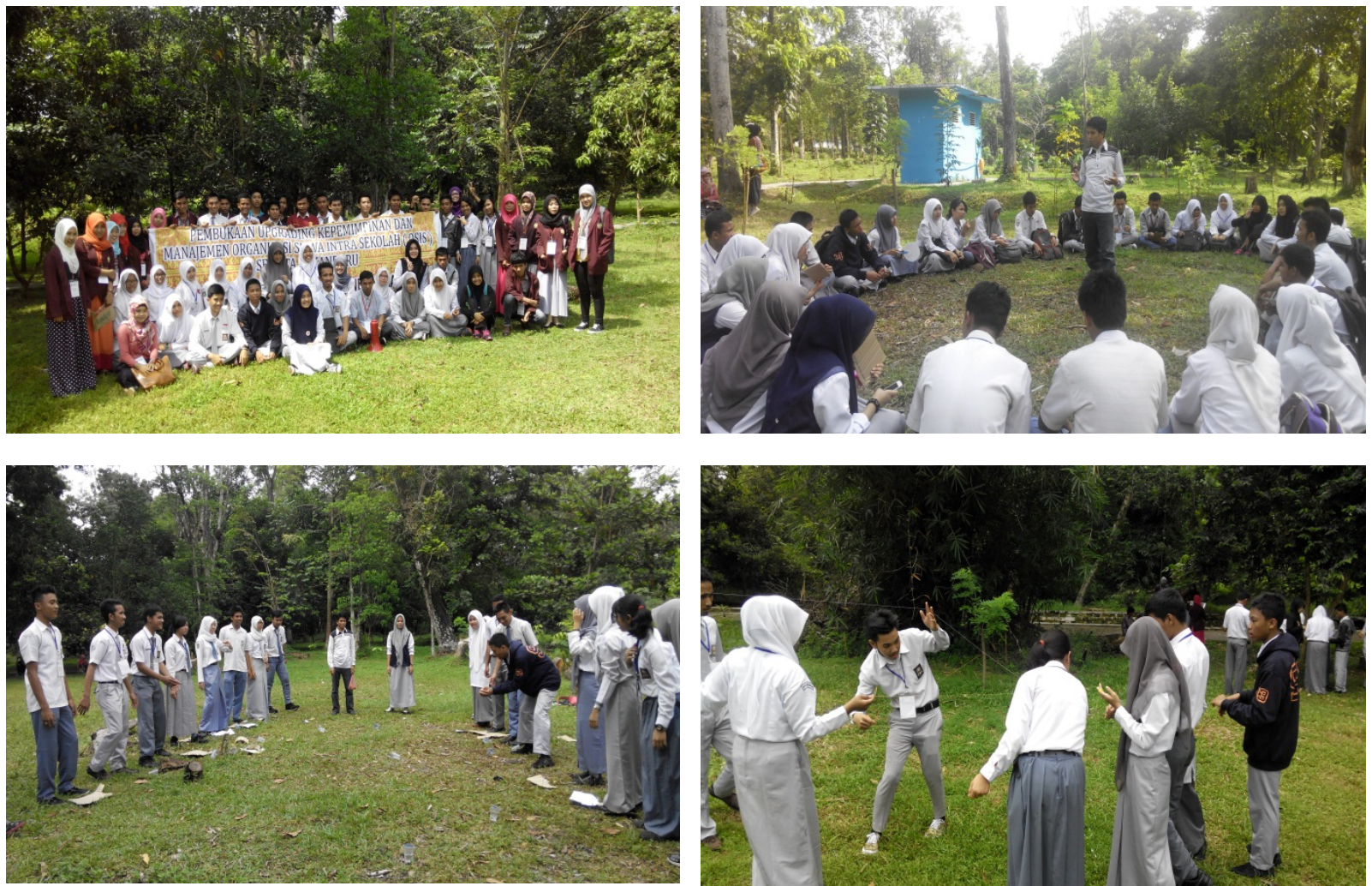
3. Rumah Dinas Wakil Walikota Pekanbaru. Wakil Walikota Pekanbaru merupakan sosok pemimpin yang memulai karirnya dari organisasi di tingkat pelajar yakni Pelajar Islam Indonesia. Pada saat kuliah, beliau juga aktif pada organisasi dakwah kampus, hingga mengantarkan beliau menjadi aktivis partai politik. Awal karirnya adalah menjadi guru hingga menjadi anggota DPRD Kota Pekanbaru selama 2 periode. Sekarang merupakan amanah yang kedua kalinya juga beliau emban sebagai Wakil Walikota Pekanbaru. Sosok seperti beliau ini akan menjadi inspirasi bagi para peserta untuk terus mengembangkan karakter kepemimpinan dan mau aktif di organisasi termasuk OSIS. Pada saat di rumah dinas ini, Wakil Walikota merupakan pembicara tunggal.

Gambar 4. Foto bersama setelah mendengarkan materi Motivasi Kepemimpinan dari Wakil Walikota Pekanbaru, Ayat Cahyadi,S.Si.

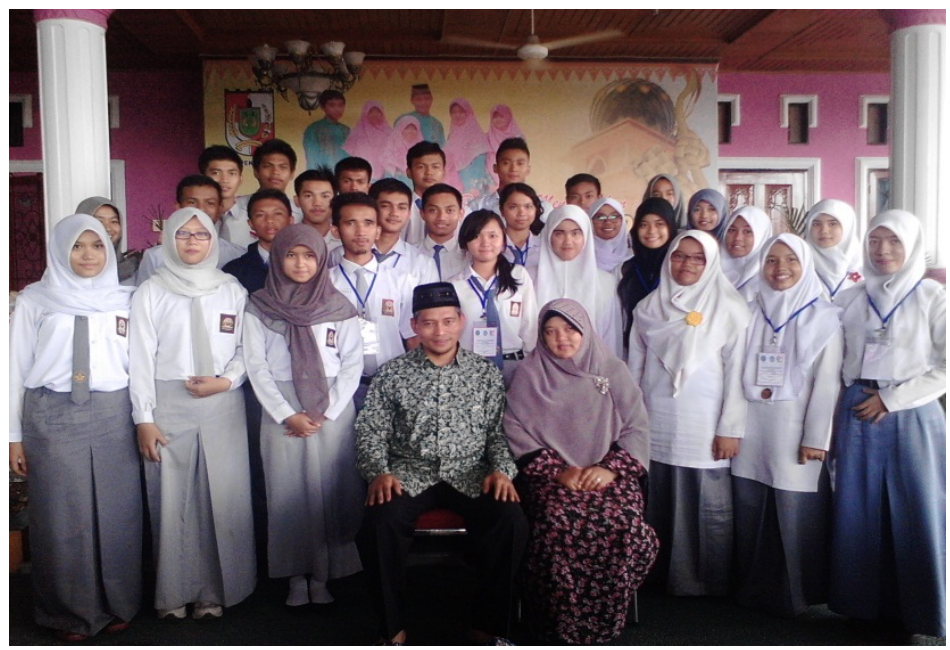

4. Car Free Day. Lokasi CFD dipilih sebagai penutup acara. Lokasi ini dilakukan penetrasi kegiatan dengan aksi pelajar untuk peduli terhadap moral remaja. Pada saat penutupan, dilakukan pemilihan pengurus dan mendiskusikan nama organisasi sebagai wadah tempat berdiskusinya seluruh OSIS di Pekanbaru. Adapun organisasinya bernama Forum OSIS Pekanbaru yang disingkat dengan FOP, dengan pengurus diambil dari tiap-tiap sekolah yang diketuai oleh ketua OSIS SMK Negeri 1 Pekanbaru.

Gambar 5. Aksi Pelajar Peduli Moral dan penetapan pengurus Forum OSIS Pekanbaru.
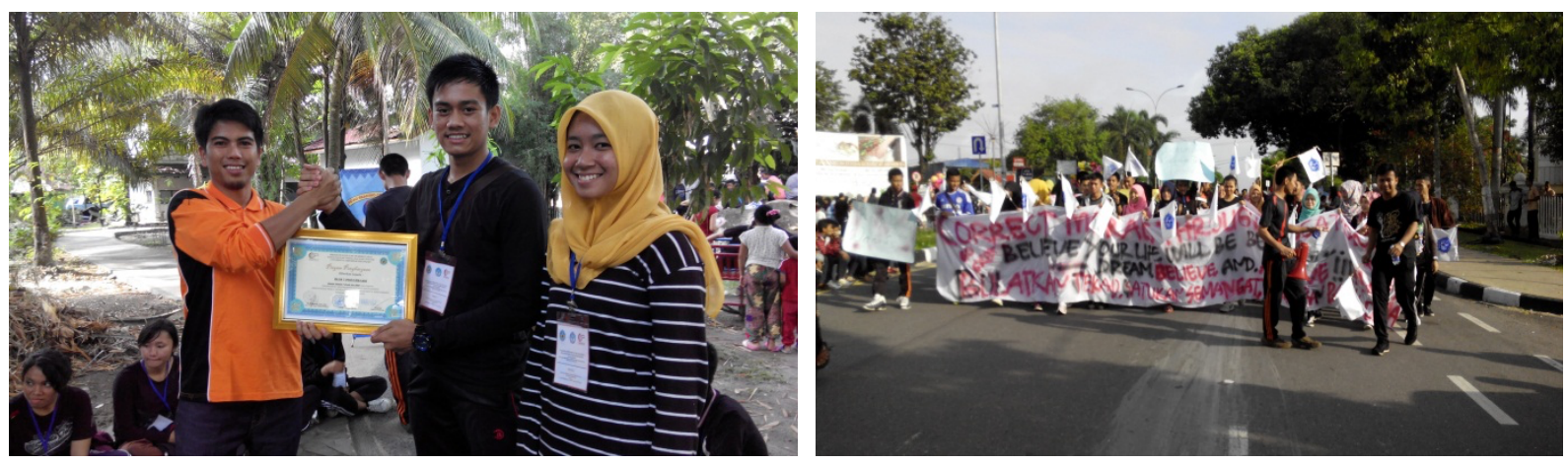

\section{e. Tingkat Ketercapaian dan Indikator Keberhasilan}

Ide melaksanakan pelatihan dan pembinaan manajemen dan kepemimpinan bagi pengurus OSIS yang notabene adalah remaja ditimbulkan dari kekhawatiran terhadap budaya hedonisme yang melanda generasi muda bangsa Indonesia. Budaya lokal dan saling peduli kurang diminati oleh generasi muda, termasuk pelajar SMA. Sifat apatis akan muncul 
dari budaya hedonisme, sehingga tidak ada lagi kepedulian dengan lingkungan termasuk dengan kelangsungan OSIS di setiap sekolah.

Dalam masalah budaya, setiap masyarakat mengembangkan pola-pola budaya yang akan mempengaruhi mereka yang hidup dalam masyarakat tersebut. Beberapa negara, komunitas, bahkan kelompok keluarga ada tekanan yang kuat untuk mengikuti dan mematuhi standar moral atau amoral dan standar hidup yang dianut pada perilaku, perasaan, sikap, interaksi, sistem nilai, pendidikan, norma kelompok, dan pada dasarnya pada semua aspek kehidupan, termasuk perilaku kreatif, misalnya: Pertama, berkhayal hanya membuang-buang waktu sia-sia. Kedua, suka bermain hanya cocok untuk anak-anak. Ketiga, sepatutnya kita selalu berpikir logis, kritis, analitis dan tidak mengandalkan pada perasaan dan firasat. Keempat, semua masalah dapat diselesaikan secara ilmiah dan dengan banyak uang. Kelima, terikat pada tradisi [5].

Pelatihan ini telah menciptakan suasana kebersamaan dan saling peduli yang disampaikan melalui materi sambil bermain. Ice breaking sebagai pengantar pengantar materi untuk saling peduli menjadi sangat dipahami oleh seluruh peserta akan pentingnya kebersamaan, termasuk dalam mencapai cita-cita sebuah organisasi di sekolah sepeerti OSIS. Suasana tersebut tergambar dari respon peserta setelah menerima materi tersebut.

Kegiatan pelatihan ini memiliki manfaat multidimensi, selain adanya proses up grading pengurus OSIS, juga menjadi proses kaderisasi bagi calon pengurus OSIS. Selain itu, para pemateri pelatihan pada pengabdian ini dibantu oleh beberapa orang mahasiswa dari Ilmu Pemerintahan Universitas Abdurrab, mahasiswa tersebut akan dapat belajar dengan mempraktikan ilmu yang diperoleh di bangku kuliah atau berbagi pengalaman tentang kepemimpinan dan manajemen kepada juniornya di tingkat SMA.

Demi kontinuitas pelatihan dan pembinaan ini, maka dibentuklah Forum OSIS Pekanbaru (FOP). FOP berfungsi sebagai wadah untuk diskusi simultan antar pengurus OSIS se Pekanbaru. FOP juga berfungsi sebagai wadah diskusi untuk masalah-masalah yang tidak hanya tentang OSIS di setiap sekolah, melainkan adalah masalah pemerintahan dan sosial kemasyarakatan. Akhirnya, kegiatan pembinaan ini akan mudah dilaksanakan untuk tahun-tahun berikutnya.

Kegiatan ini akan dievaluasi dengan metode memantau pertemuan-pertemuan yang dilakukan oleh pengurus FOP. Setelah kegiatan pengabdian selesai, maka tim dan mahasiswa yang telah melaksanakan kegiatan juga akan terus melakukan pemantauan. Proses penggantian pengurus FOP akan melibatkan tim pengabdian. Tim juga akan membantu merumuskan Anggaran Dasar dan Anggaran Rumah Tangga FOP yang akan disahkan pada saat musyawarah penggantian pengurus pada tahun 2018 .

\section{KESIMPULAN}

Pelatihan dan pembinaan tidak hanya selesai pada saat kontrak kegiatan pengabdian pada masyarakat saja, melainkan akan terus dilakukan pembinaan secara intensif hingga Forum OSIS Pekanbaru bisa mandiri dan berfungsi sebagaimana tujuan awal pembentukanya. Keberhasilan kegiatan ini akan dapat dirasakan ketika OSIS setiap sekolah melakukan inovasi-inovasi kegiatan dan peduli tidak hanya pada lingkungan sekolah saja, melainkan juga pada pemerintahan dan sosial kemasyarakatan. Kepedulian tersebut muncul berupa diskusi dan aksi nyata yang dilakukan secara bersama-sama oleh pengurus OSIS se Pekanbaru. Pemerintah tidak akan lagi menganggap pelajar sebagai objek politik semata, melainkan harus dilibatkan dalam pemuatan keputusan politik terutama terkait dengan masalah pelajar itu sendiri. 


\section{DAFTAR PUSTAKA}

1 Nursyaidah. 2014. Manajemen dan Kepemimpinan. Jurnal Darul Ilmi Vol.02, Nomor 02 .

2 Siagian SP. 2013. Teori dan Praktik Kepemimpinan. Jakarta. Rineka Cipta.

3 Slamet M. 2002. Kepemimpinan. Jakarta. Rineka Cipta.

$4 \quad$ Ginting P. 1999. Pemimpin dan Kepemimpinan. Medan. USU Press.

5 Veithzal. 2004. Kiat Memimpin dalam Abad 21. Jakarta. Raja Grafindo Persada. 